\title{
A dimensão ética da palavra
}

\author{
FRANKLIN LEOPOLDOE SILVA
}

Para Valentim Faccioli

RESUMO: Num mundo marcado pela violência e pela desintegração de valores, a palavra ainda pode servir de elemento para a constituição ética do indivíduo, em termos de autoconhecimento e de percepção do outro? Esta é a questão considerada no texto, a partir do comentário de alguns aspectos do filme $O$ carteiro e o poeta.

UNITERMOS: palavra, valor, conhecimento, resistência, o carteiro e o poeta.

Aula inaugural do Departamento de Filosofia, proferida em 29/2/96.

Professor do Departamento de Filosofia da FFLCH-USP 
pretexto o comentário da situação dos irmãos que emigraram para a América, é na verdade um monólogo duplamente transgressor: do silêncio do pai e da recusa do ofício. Tanto é assim que o emprego de carteiro aparece como uma reparação da transgressão, imediatamente motivada pela censura do pai quanto à ociosidade de Mario. Mas esta palavra transgressora do cotidiano se encontrará então com uma outra palavra, que também se constrói na experiência da transgressão nos planos da linguagem e da política, a palavra do poeta exilado. Toda a narrativa se construirá seguindo o eixo desta intimidade latente entre dois sentidos de exílio: o estranhamento espontâneo de Mario em relação ao seu meio, de um lado, e a punição do poeta pela sua palavra comprometida, de outro. A revelação da palavra como transgressão política se dá quando o poeta, por ocasião do recebimento de uma fita de seus companheiros chilenos, narra ao carteiro o nascimento da palavra comprometida com o sofrimento, a origem do Canto geral. E a revelação da transgressão lingüística ocorre quando o poeta explica a Mario que a metáfora é a linguagem da poesia, e principalmente quando acrescenta que a explicação da metáfora é inútil e indevida, por fazer com que a poesia regrida à banalidade. $\mathrm{O}$ duplo compromisso da palavra poética, com a transfiguração do sentido e com a tarefa de tornar poesia o clamor do sofrimento humano, aparece na forma da transgressão, como se a gênese da palavra autêntica dependesse sempre da recusa do significado dado e da história dada. Mas estes exemplos só calam no carteiro porque nele já existe uma primeira recusa, a sua própria transgressão do silêncio. A recusa fundamental e a metáfora originária dizem respeito a este primeiro ato de construção do Eu ou de encontro de si: assim como a metáfora é transferência de significação da inércia da linguagem prática para o ensaio criador que rompe o limite do utilitarismo da palavra, assim também o fundamento da transgressão do limite é a liberação da subjetividade que se confunde com o encontro de si. Neste processo de ressignificação a palavra é muito mais do que instrumento: é o medium formador da visão do mundo, é o abandono da percepção cega e o achado da trama interna da linguagem que revela a negatividade do real e a positividade da utopia. Da necessidade de uma palavra que apenas substitui o silêncio à liberdade das significações contingentes, a expansão da consciência ocorrerá não apenas em termos de latitude descritiva das coisas, mas sobretudo como flexibilidade significativa que aprofunda o valor expressivo da linguagem. Será o peso da relação entre palavra e liberdade que fundamentará o compromisso de identificação entre o homem e a palavra, cuja assunção envolve um risco que é proporcional à transgressão que a palavra opera. A morte de Mario será o testemunho maior desta dimensão transgressora.

A palavra, por ser transgressora, transforma. Em primeiro lugar, no nível do processo afetivo da história pessoal e interior. Daí a íntima conexão entre a palavra e a paixão, seja naquilo que ela produz no amante, seja naquilo que ela desperta no ser amado. Por isto a palavra mostra-se essencialmente como requisito da realização do amor: Mario se compreende na expressão 
emprestada do amor que sente por Beatriz, e esta somente corresponde ao amor que lhe é devotado a partir das palavras que ao mesmo tempo a descrevem e descrevem o amor de quem as profere. Porque Beatriz o ama amando as palavras que ele fala, muito embora tais palavras não sejam de Mario, mas do poeta. A relação de exterioridade que existiria em princípio entre as palavras e quem as dizia é amplamente compensada pela verdade intrínseca da palavra poética, atestada na fala da tia de Beatriz: a poesia não mente, e o efeito da palavra poética transcende o seu criador. O outro sentido da transformação operada pela palavra aborta no limiar da ação histórica e no nível da proficiência política da linguagem. Por isto, neste plano, os resultados do dizer são o exílio do poeta e a morte de Mario. Importa observar que não há qualquer separação entre o processo afetivo do encontro de si e do encontro do amor através da palavra, de um lado, e a face política da palavra. É sugestivo, quanto a isto, que Mario morre numa manifestação na qual o seu ato político seria dizer uma poesia. Este fato estabelece uma continuidade entre o encontro de si e o encontro da história, entre a construção do sentido do si mesmo e a esperança na transformação histórica. Na cena da repressão aos manifestantes, a personagem direta é a folha em que estava escrito o poema, é ela que alude à morte como interrupção da palavra, como separação entre o homem e a sua palavra. Quando Beatriz narra ao poeta a morte do marido, o que ressalta, na linha de continuidade que mencionamos há pouco, é a relação entre o processo afetivo que ligava o carteiro ao poeta e o compromisso ético-político com a palavra. É pelo poeta, pela causa, por si mesmo, pelas idéias que lhe são quase desconhecidas, pelos seus compatriotas explorados, pela sua ilha que o carteiro morre, e todos estes motivos estão intimamente entrelaçados, no mesmo amálgama que na poesia une o amor e a indignação, a dor e a beleza. Seria ocioso tentar descobrir o motivo de sua participação buscando-o em alguma perspectiva mais firme de uma consciência política subitamente esclarecida. Na verdade, a palavra encerra todas as descobertas, ela contém o amor, a vida, a história, a esperança, a amizade, a crítica, a revolta, a solidariedade. Isto não significa que ela proporciona um aprendizado, no sentido comum do termo. A relação entre o carteiro e o poeta não é mediada por qualquer forma de pedagogia. Se quisermos falar de aprendizado, teremos de dizer que Mario aprende consigo e a partir de si mesmo. De alguma maneira a palavra torna-o aquilo que ele já era. Por isto ele não precisa ser o homem "esclarecido", iluminado pela racionalidade política. A palavra o faz, atualizando a integridade humana latente na sua espontaneidade, no caráter primário de suas recusas e de suas opções. A palavra o faz, a palavra o toma. No recitativo aparentemente mecânico com que diz a Beatriz as palavras que aprendeu do poeta aparece, cenicamente, a primazia da palavra sobre quem a diz, quase como uma transmissão oracular. Por isto o sentido que de sua fala emana, e que chega a Beatriz, salta por cima das etapas semântico-analíticas e é apreendido na originalidade intencional de palavras que são ditas pela primeira vez. É como se as palavras se apropriassem dele quando delas ele se apropria. E esta 
intensidade é proporcional ao tempo de silêncio, à longa privação da palavra, que se revela então não simplesmente carência, mas gestação. Daí o poder quase palpável, e a força de transformação que a palavra encerra na sua realidade ainda não desgastada pela inércia do uso. Daí também o privilégio da palavra poética, que revela a invenção significativa fazendo brotar a diferença a partir do mesmo, a metáfora como a surpresa que as velhas palavras escondem. De tudo isto se infere que a palavra é essencialmente portado$r a$ : o sentido não é apenas meio de intelecção, mas força produtora. Portadora, o que a palavra traz?

O poeta revela a Mario aquilo de que se fez portador pela palavra, ao narrar o episódio do encontro com os habitantes do inferno, as minas de cobre do Chile. Onde quer que fosse, deveria falar daquele sofrimento. O que passa através da palavra? Qual a força que sustenta a elaboração das metáforas com que se constrói a poesia? O que torna a metáfora transparente ao sentimento a partir de sua própria opacidade ao entendimento? Todas estas questões se resumem na pergunta inesperada: que devo fazer para me tornar um poeta? A ausência de resposta não se deve apenas à impossibilidade explicativa, ou à inefabilidade daquilo que faz o poeta. Deve-se a que a resposta já está dada como pressuposto da pergunta. A poesia já habita aquele que a deseja. O encontro com a palavra poética será, entretanto, a descoberta de que o sentido da palavra identifica-se com o seu valor. O que vale a metáfora poética? Vale o que nos faz apreender sentimentalmente acerca do amor e do sofrimento. Por isto o poeta cumpre historicamente o destino lírico: fala do sofrimento causado pela opressão, tema do Canto geral. A narração do sofrimento é por si mesma uma tarefa grandiosa, para o cumprimento da qual há que se mergulhar no mistério pelo qual a poesia recria liricamente a história. No entanto, não parte da descrição nem pretende chegar a ela. A palavra poética jamais nomeia com neutralidade, porque a intencionalidade lírica produtora de metáforas é inevitavelmente comprometida - ainda que seja com a emulação do status quo, como no caso do poeta preferido do político conservador, D' Annunzio. Por isto a palavra poética não se subordina àquilo que descreve, pois no compromisso que a sustenta está inscrita a transfiguração, que no caso se traduz em transgressão e transformação. Neste sentido, a descoberta da força produtora da palavra é a compreensão de que ela se iguala ao que é, deixando transparecer na relação significativa que aquilo que é tornase também valor ao se incorporar no universo humano. É a identificação entre o sentido e o valor que torna impossível a neutralidade da palavra.

Então, se ofalar de não remete a palavra à pura transcrição simbólica do que simplesmente existe, há algo que sustenta a palavra num estágio anterior ao processo de consolidação do significado. A palavra é sustentada por aquilo que ela constantemente reitera: a integridade ética da fala que intervém no mundo. Se falar de é igualar a palavra ao que é e nomear valorativamente o que é, a força produtora da palavra implica a construção da realidade, como está inscrito no alcance da relação poiesis/poesia. A poesia 
nomeia a realidade através da construção de um sentido que é valor. Por isto a palavra, ao dizer, julga, e não é possível a relação neutra com o referente: não é possível falar com indiferença da falta de água e do preço dos peixes, dois episódios que ilustram no filme o compromisso da palavra com a história vivida. O que é sofre uma transmutação axiológica quando passa a habitar a palavra, há sempre uma mediação ética e a naturalidade da coisa perde-se irremediavelmente na significação. Daí a insuficiência de se considerar apenas a causalidade eficiente do significante; a intencionalidade significativa corporifica na palavra a finalidade a partir da qual ela é dita, a direção da transgressão e da transformação. Tal finalidade está expressa no próprio caráter abortado de que se reveste, na cena da folha em que está escrita a poesia de Mario, vagando abandonada e sem direção em meio ao tumulto da repressão. Quanto a isto há que se assinalar o contraste profundo entre as cenas iniciais do noticiário, em que a palavra descaracterizada e midiática descreve a chegada do poeta à Itália, banalizando o exílio e suas causas histórico-políticas, e as últimas cenas, caracterizadas pelo silêncio da palavra cuja finalidade foi abortada: a folha perdida que relegará a palavra ao esquecimento, e o passeio do poeta na praia que teria a função de inspirar as metáforas e tornada agora apenas moldura do silêncio. O que põe em questão a causa da palavra, o que a move e aquilo a que se destina, o que a desperta e a instância última do seu objetivo. Questão que certamente não seria aprofundada se a tratássemos apenas nos termos da função comunicativa estereotipada na exterioridade da relação significativa. A transitividade da expressão só se realiza quando a palavra impressiona, além ou aquém da inteligibilidade funcional do jogo da linguagem. Por isto a metáfora proporciona a corporificação que permite a densidade afetiva, como no exemplo do poeta: o céu chora, ou, mais ainda, naquilo que o filme mostra como o fio condutor da narrativa: a comunhão simpática e incompreensível entre o poeta e aquele que traz em si a poesia. Talvez o episódio que marca mais profundamente a imanência da expressividade seja a gravação que Mario pretende enviar ao poeta: o vento, o mar, as redes de pesca, o coração do filho e, sobretudo, o céu sobre a ilha. Como tudo é metáfora de tudo, já havia dito Mario, a expressão direta da natureza a faz falar de si mesma, antes que o poeta fale da natureza. Mais do que isto: a audição da natureza é a gênese da poesia, é a gênese da palavra, pois não se trata simplesmente da natureza em si, mas daquela que o poeta mostrou a ele, quando contrastou a miséria e a passividade dos habitantes com a beleza da ilha, indicando que a apreensão humana da beleza se sustenta na dignidade com que o homem se apreende a si mesmo. Por isto é esta a poesia que ele deve mostrar ao poeta. E a naturalidade com que ele aponta o microfone para o céu é profundamente significativa da crença na poesia e no poeta. Pois se o poeta não pudesse ouvir o céu, como o transformaria em palavras?

Somos postos assim diante de uma concepção da palavra, segundo a qual ela transtorna a realidade e subverte a história. Se ampliarmos a questão para além do caso particular do poeta de que trata o filme e da relação 
singular entre o poeta e o carteiro, o fundo da narrativa a que seríamos conduzidos seria talvez a relação entre o homem e a palavra. O dizer que transtorna e que transforma continuaria presente como lastro desta relação neste plano mais geral? Se associássemos a esta pergunta o problema referente ao propósito da palavra poderíamos encontrar em Aristóteles elementos para pensar a questão. Com efeito, na Arte retórica, lemos: "A Retórica é útil porque o verdadeiro e o justo valem naturalmente mais do que os seus contrários. Donde resulta que, se os julgamentos não forem feitos como convém, o verdadeiro e o justo serão necessariamente sacrificados, resultado censurável"(Aristóteles, 1944, I, IV, 12). O que Aristóteles enuncia vale como um princípio, não no sentido da ciência, mas no sentido do fazer e da conduta, já que a retórica é uma arte. A utilidade da retórica consiste em fornecer os meios para persuadir do que é justo e verdadeiro, muito embora não seja a própria retórica que forneça os meios para discernir o que é justo e verdadeiro. Esta diferença entre persuadir e discernir nos coloca diretamente diante do problema do emprego da palavra. A retórica em si mesma pode a princípio persuadir do que é injusto e falso, e é útil para o orador possuir a habilidade para argumentar inclusive contra si mesmo, pois é isto que o habilitará a vencer a discussão com outro. Mas esta neutralidade técnica da retórica contrapõese a uma censura da indiferença moral. "Enfim, é preciso estar à altura de persuadir do contrário de nossa proposição, do mesmo modo que nos silogismos lógicos, não para nos entregarmos indiferentemente às duas operações pois não devemos persuadir do que é imoral - mas para ver claro na questão e para estarmos à altura de reduzir por nós mesmos a nada a argumentação de um outro, caso este não respeite a justiça em seu discurso" (Aristóteles, 1944, I, IV, 12). Argumentar pró e contra é útil como desenvolvimento de habilidade técnica para que se possa refutar argumentos. Mas esta habilidade formal tem um propósito, que escapa à indiferença formal da técnica argumentativa. A habilidade deve ser usada para refutar aquele cujo discurso fere a justiça. A relação entre retórica e ética aparece então com clareza, pelo menos nestes textos, muito embora a motivação do estabelecimento desta relação esteja na neutralidade técnica da retórica. A necessidade de estabelecer uma relação de exterioridade entre as duas formas de saber prende-se ao contexto político que é a última instância de compreensão da retórica. Daí a analogia com os bens, que podem ser usados de maneira justa ou de maneira indevida, sem que por isto sejam em si mesmos condenáveis. "Poder-se-ia objetar que o uso injusto de semelhante faculdade de palavra pode causar grandes prejuízos; mas este inconveniente é comum a todos os bens, com exceção da virtude, até particularmente aos mais úteis, como a força, a saúde, a riqueza, a arte militar"'(Aristóteles, 1944, I, IV, 13). A dimensão ético-política regula o uso da "faculdade de palavra", cuja finalidade é a utilidade cívica na forma do estabelecimento das melhores condições para que ocorram os melhores julgamentos, isto é, para que a justiça e a verdade prevaleçam. Neste sentido a persuasão possui um propósito que atua como causa final no emprego da 
habilidade técnica de quem faz o uso oratório da palavra. O impacto da palavra está inscrito na dimensão disposicional a ser criada no ouvinte, um dos meios de persuasão; mas este meio vincula-se a um outro, que Aristóteles enuncia em primeiro lugar: o caráter moral do orador. "Muito errônea é a afirmação de certos autores de artes oratórias, segundo os quais a honestidade do orador não contribuiria em nada para a persuasão do discurso. Bem ao contrário, o caráter moral deste constitui, por assim dizer, a prova determinante por excelência" (Aristóteles, 1944, II, II, 4). Há mesmo uma relação entre a honestidade do orador e a disposição criada no ouvinte, uma vez que a qualidade da paixão suscitada no ouvinte (naqueles que julgarão) depende, ao menos em parte, daquilo que o orador os faz sentir acerca dele mesmo. A combinatória entre a honestidade do orador, a disposição passional criada no ouvinte e a demonstração argumentativa propriamente dita não está isenta de uma linha criteriológica que amarra a utilização dos meios às finalidades da retórica, ou à sua "utilidade" para a apresentação do verdadeiro e do justo na argumentação moralmente justificada. O compromisso com a justiça, o impacto na sensibilidade e a argumentação demonstrativa colocam em equilíbrio os aspectos da complexidade da palavra, quando esta se destina a nos fazer compreender o universo das coisas humanas e nele agir. Se a verdade humana não se separa das oscilações da alma, é necessário que ela brote da contingência em que mergulham as condições dos nossos juízos para que corresponda à realidade originária da inelutável desordem do mundo dos homens, que a palavra busca expressar na transcendência da sua configuração significativa. A palavra que procura dar a compreender a ética ao sábio, a política ao político, a história àquele que a faz não busca superar a contingência, mas construir, nela, um abrigo que nos preserve da hybris. É nesta perspectiva que assume relevância o compromisso de quem emite a palavra, figurado na intencionalidade eticamente agregadora do mundo humano que deve compor o emprego da faculdade da palavra.

Os meios de persuasão são utilizados para afirmar aquilo que o orador defende e também para se contrapor àquele "que não respeitasse a justiça no seu discurso"(Aristóteles, 1944, I, IV, 12). Esta negatividade inscrita na função da palavra nos faz reencontrar indiretamente os temas mencionados na primeira parte desta exposição. A faculdade da palavra eticamente regulada não instaura a justiça e não desvela epistemicamente a verdade, mas apresenta o justo e o verdadeiro no encadeamento persuasivo do discurso, que se torna assim o modo pelo qual a contingência humana incorpora de alguma maneira a ordem transcendente das formas e dos valores, recompostos na esfera da imprevisibilidade dos atos humanos. A eficácia deste logos que não pode contar com a segurança da necessidade analítica e metafísica dependerá do equilíbrio entre o indivíduo e a comunidade ético-política na qual está inserido. A efetividade desta relação é que confere papel positivo à retórica, e faz com que a palavra possua força produtora de realidade prática. Assim, quando o teor ético da relação comunitária entra em processo de dissolução, 
desaparece a identificação entre sentido e valor, e a palavra decai para a dimensão físico-inerte da naturalidade e do estímulo associativo. O registro imediato da nomeação utilitária é tudo que resta à linguagem. Em épocas caracterizadas por tal estado de indigência moral, a ativação da dimensão axiológica da palavra aparece como transgressão da atualidade: não só a palavra poética, mas toda palavra autêntica aparece como resistência.

Esta resistência enfrenta primeiramente a banalização da palavra, cuja causa profunda poderia ser encontrada na separação entre ética e cultura. A integridade ética do sujeito depende de referências que o imanentismo e a dessacralização do mundo destruíram. O esvaziamento ético do mundo corta a possibilidade de fundamentar a ação numa racionalidade prática específica; a prática torna-se apenas o campo de aplicação da razão técnica e instrumental. Tem portanto o seu perfil próprio dissolvido no imediatismo da satisfação racional das necessidades, à qual se aplica a razão industriosa. Desta maneira, a organização das relações intersubjetivas já não se ordena ao valor da intersubjetividade, pois a integridade mesma do sujeito foi rompida pela impossibilidade de sua relação com a totalidade. Assim a compreensão autêntica, nos seus eixos totalizador e comunitário, torna-se impossível. Por isto a palavra já não remete a um contexto de ação histórica, mas a um quadro de passividade em que ela é recebida a partir de um sentido extrínseco ao interesse do sujeito, consumida como um produto de cuja gênese não participamos. A vitória ideológica da produção anônima obscurece o processo de produção de sentido, e perde-se qualquer liame entre representação e liberdade, contrariando, na sua intenção explícita pelo menos, o projeto originário da modernidade. A nomeação já não é mais contemporânea do ato criador, e a imposição anônima do sentido apenas reitera a forma de código que vai assumindo cada vez mais a nossa maneira de nos referirmos às coisas e aos outros. Não é surpreendente que neste contexto a anatomia da linguagem passasse a ter a importância que hoje se lhe atribui. No entanto, a consequiência mais sugestiva talvez apareça na tendência da literatura a falar de si mesma, que observamos desde a segunda metade do século XIX, tanto nos casos em que a poesia se torna o tema do poema quanto nas experiências de minimalização do conteúdo narrativo no romance. Considera-se que seja este fenômeno uma alternativa de resistência num mundo em que a lírica e a narrativa perderam o poder da designação criativa. "A poesia, reprimida, enxotada, avulsa de qualquer contexto, fecha-se em um autismo altivo; e só pensa em si, e fala de seus códigos mais secretos e expõe a nu o esqueleto a que a reduziram; enlouquecida, faz de Narciso o último deus"(Bosi, 1977, p. 143). A relação entre narcisismo e consideração da linguagem como código indica a profunda separação entre a linguagem e a nomeação originária, o que seria quase o mesmo que dizer entre a linguagem e si própria, separação que se revela no autismo literário de certas tendências modernas. Ao isolar-se, tornando-se objeto de si mesma, a linguagem literária busca salvar a palavra da banalização que o objetivismo técnico da racionalidade comunicativa 
acarreta na contemporaneidade.

Mas há um outro aspecto da resistência que procura, talvez de forma mais efetiva, alguma possibilidade de liberação da palavra. A ausência de efetividade ética nas relações intersubjetivas faz com que apareçam como, mitos possibilidades históricas recalcadas pelo trabalho da ideologia. Aqui, mito adquire a mais banal de suas significações, a de procedimento explicativo pré-racional que proporciona a assimilação da situação humana e de seu contexto ao ideário que rege a vida histórica. Quando as possibilidades de futuro, no que concerne à transformação histórica, são nomeadas como mitos, no sentido mencionado, a justificação do presente mostra-se como a única atitude dotada de racionalidade. E assim, prolongar o presente e aprofundar suas tendências, num processo de atualização reiterativa sem diferenças, seria a única forma de dar continuidade à falsa positividade que é nomeada como progresso. É desta forma que a liberdade que se manifestaria nas rupturas possibilitadas pela temporalização e pelo livre assumir da herança histórica tem decretada a sua impossibilidade ou o seu non-sense. Entretanto, há um outro sentido de mito, aquele em que a incorporação da memória na compreensão crítica do presente libera o sentido positivo da temporalidade. Nesta acepção o mito nunca é uma cópia de um registro no passado; é sempre meio de expressão de algo a que se aspira no presente. $O$ sentido amplo da temporalidade não combina com o tempo vetorial, tampouco com o puro retorno cíclico eventualmente desejado em termos de simples nostalgia. A vivência de dois tempos, o histórico-progressivo, tempo do desenvolvimento, e o tempo da memória que constrói as diferenças na medida em que o presente é provocado pelo passado, constitui a especificidade da temporalidade humana, em que o presente remete a uma abertura anterior indefinida e constante objeto de decifração. No cruzamento destes dois tempos é que o mito aparece como operador de compreensão do sentido temporal do presente, que não se esgota numa cronologia descontínua. "O tempo vetorial, que passa do inconsciente à consciência, o ‘desenvolvimento’ de Hegel, a passagem da pré-história à história de Marx, coexiste e cruza com o tempo cíclico no qual o mesmo inconsciente recobra periodicamente a sua força e a sua voz. Nada se perde nesta concordia discors. Ao contrário, algo de novo parece que surge: a consciência tem, no mundo moderno, a ciência daquela dualidade de tempos"(Bosi, 1977, p. 158). Este tipo de relação com o passado, em que a memória funciona como operador de compreensão crítica, não desfruta de prestígio na modernidade mais recente, por compor-se mal com a ideologia do progresso contínuo e da auto-suficiência do presente. Esta oposição atinge o limite quando pensamos na diferença entre a palavra mitopoética e o termo reificado com que designamos imediatamente as coisas e - o que é ainda pior - certas idéias que devem passar como slogans em palavras desprovidas de qualquer densidade interna. O esquecimento da história das palavras é condição primária da mistificação. Esta é a razão pela qual a linguagem "política" a que estamos habituados constitui-se quase exclusivamente de clichês ape- 


\footnotetext{
" A responsabilidade social do poeta se dá, antes de tudo, em relação à sua língua. Ao exprimir o que outras pessoas sentem, também ele está modificando seu sentimento ao torná-lo mais consciente. Ele está tornando as pessoas mais conscientes daquilo que já sentem e, por conseguinte, ensinando-lhes algo sobre si próprias" (Lima, 1995, p. 85).
}

nas reiteradores de estímulos sonoros e visuais que remetem a sentidos estereotipados e desvinculados de um contexto social interativo. $\mathrm{O}$ esquecimento da história das palavras está inscrito numa dimensão mais ampla de recusa da memória como sustentáculo da temporalidade histórica. Aí situa-se também a causa da recusa do mito enquanto arquétipo do passado e referência interna da constituição da história. O contraponto destas recusas é a justificação do presente na sua atualidade isolada. A remissão ao passado é vista como atitude conservadora e romântica, portanto reacionária. O que ressalta neste estigma é a indiferença da nossa época à sua própria perda de substância ética e histórica. Se este diagnóstico é correto e se a ele chegamos por meio de referências a tempos passados, isto não significa um simples culto ao passado, mas uma leitura crítica do processo histórico. A este respeito são decisivas as palavras de Alfredo Bosi: "A saudade de tempos mais humanos nunca é reacionária [...]. Reacionária é a justificação do mal em qualquer tempo. Reacionário é o olhar cúmplice da opressão. Mas o que move os sentimentos e aquece o gesto ritual é sempre um valor[...]" (Bosi, 1977, p. 153). Se a palavra puder retirar da memória algo que contribua para o resgate da compreensão histórica da gênese de nós mesmos, ela cumprirá a função axiológica que o processo de dissolução ética da contemporaneidade impede o nosso presente histórico de cumprir. E nisto consiste a relação entre memória e resistência. A memória institui o lugar a partir do qual se gera a interrogação que delineia o campo de nossas perplexidades.

Palavra: memória e resistência. Teria sido uma identificação entre verdade e história o fundamento do processo que produziu uma situação somente interpelada por uma palavra que resiste a este próprio resultado? Se não pudéssemos questionar a verdade da história, de onde surgiria a palavra resistente? Se não houvesse um outro lugar de onde o falar se constitui contra os códigos alienantes da linguagem plana e planificada, como seria possível a resistência? Ela nos mostra, ainda que indiretamente, que a palavra encerra possibilidades não inteiramente aprisionadas nos limites da reificação e do tecnicismo. É possível proferir a verdade contra a história presente, mesmo que esta oposição não escape inteiramente às condições de expressão próprias da indigência histórica do nosso tempo. $\mathrm{O}$ autismo da linguagem poética e o esvaziamento da narrativa, a que já nos referimos, são ilustrações de uma atitude ensimesmada de contestação. $O$ peso da história produz a contradição inscrita no protesto auto-referente e por vezes quase mudo. Mas a ação histórica que contesta a verdade da história se dá no âmbito da contradição. Por isto a palavra se volta para dentro de si mesma quando a transgressão da linguagem não produz o efeito liberador da consciência, quando já nem mesmo a poesia em voz alta consegue se fazer ouvir, e o poeta se vê compelido a reconstruir na esfera da subjetividade a expressão das possibilidades históricas que não encontram eco no mundo que o rodeia ${ }^{1}$. A vocação histórica da palavra poética está na identificação das referências universais do sentimento, expressas na particularidade de cada língua e de cada repertório cultural e afetivo. E isto 
SILVA, Franklin Leopoldo e. A dimensão ética da palavra. Tempo Social; Rev. Sociol. USP, S. Paulo, 8(2): 53-66, outubro de 1996.

é apenas o limite da vocação de toda palavra expressiva. Quando esta expressão não logra reconstituir o tempo humano da comunhão poética, constata-se o fracasso da palavra na sua reverberação histórica e social. A resistência é também então, forçoso reconhecê-lo, a palavra acuada, enxotada, expulsa e avulsa, de que fala Bosi. É o esvaziamento da dimensão eticamente agregadora da palavra que corta o vínculo entre poesia e realidade humana e entre narrativa e história.

A possibilidade da palavra se institui no enfrentamento destas impossibilidades, e é de modo um tanto esquivo que ela cumpre historicamente o seu modo possível de existir. Para subsistir numa cultura que requer o seu sepultamento sob a banalização dos estereótipos que dispensam a função nominativa do mundo, a palavra fará da necessidade virtude, isto é, exacerbará o regime reflexivo que se torna signo da transitividade impossível ${ }^{2}$. Neste sentido a introspecção não pode mais ser considerada como o impulso interior de uma apreensão livre das coisas, de um falar de que se estruturasse sobre o equilíbrio entre a impressão e a expressão. Opera-se uma cisão entre os elementos que deveriam estar em continuidade e a linguagem reveste-se de um teor dramático caracterizado pela divisão irreversível entre o dizer e o que é dito. A recusa da narrativa não é uma opção estética. É o recolhimento, a incorporação de uma impossibilidade histórico-cultural, e reflete um processo de intimidação da palavra, de diminuição de seu alcance e da perda de seu poder de ordenar a praxis. O mundo deixa de ser dizível porque a palavra já não porta em si a possibilidade de conferir, pelo sentido, valor ao ato de dizer, e de imprimir este valor na doação de sentido. A palavra despojada de valor é ameaçada pelo silêncio, não o silêncio da gestação do discurso, mas o silêncio inconsciente de sua própria negatividade e vazio das expectativas de sua própria superação. Este despojamento se reflete na ausência do sentimento de posse por parte daquele que detém a palavra, seja o escritor, seja o filósofo. Possuir a palavra não é estar de posse de algo que real e singularmente exista no mundo, istoé, produza efeitos: a palavra está distante da ação na mesma medida em que o valor está distante da realidade prática. A impossibilidade de emitir verdadeiramente e de receber verdadeiramente - a impossibilidade de falar e de ouvir - acarreta a perda da identidade moral, se consideramos a palavra na perspectiva do sentido e do valor. Por isto a pseudo-existência da palavra - a existência da palavra banalizada - repercute na impossibilidade de construção de um vínculo efetivo entre as esferas da existência, cada uma delas irremediavelmente marcada por uma insuficiência que advém do seu próprio isolamento. Pois a palavra agregaria os modos de participação em tudo que diz respeito à realidade humana ${ }^{3}$.

E assim reencontramos, mas agora bem mais carregada de negatividade, a concepção da palavra como transgressão do silêncio. Mas também somos capazes de ver que não se trata mais do silêncio que antecede a palavra, mas daquele que a corta, com violência, antes mesmo que ela venha a existir. E é esta relação entre silêncio e violência que confere a específica
2 Benedito Nunes aponta de forma exemplar esta tendência na obra de Clarice Lispector. $\mathrm{Na}$ tentativa de transcender a esfera pessoal e atingir um universo que transborde a subjetividade, a narração exacerba a expressão da reflexividade, criando o equívoco de um Eu que se nomeia a partir de um lugar exterior a ele mesmo, de alguma maneira duplicando a flexão indicadora do si-mesmo. "Mas para quem narrar é sempre narrar-se, essa palavra mínima de uma única letra (é), submete-se ao regime reflexivo do si mesmo, indicando, em vez da apropriação subjetiva, a pertença ao âmago impessoal que transborda do pessoal". O texto comentado por B. Nunes inicia-se com a expressão "Sou-me" (Nunes, 1989, p. 158).

3 Ainda aqui a análise que B. Nunes faz da obra de Clarice Lispector ilumina o problema geral da dimensão ético-existencial da palavra. "Na concepção do mundo de Clarice 
Lispector, a liberdade é uma potência negativa. Nostalgia de Deus como nostalgia de nós mesmos, impele-nos, através do desejo de ser que se requeima na paixão da existência, na direção deste outro, a nós oposto tanto nas coisas quanto no desdobramento do eu desagregado, e que também somos nós. [...]. A esta mesma perspectiva se ajusta a acepção equívoca da própria idéia de existência na obra de Clarice Lispector, ora atribuída à realidade irredutível, mas insuficiente, do sujeito humano, ora à realidade auto-suficiente, mas não humana, do ser [...]. Mas a equivicidade da idéia acompanha [...] o descentramento do sujeito, a perda de sua autonomia substancial, de sua identidade espiritual" (Nunes, 1989, p. 127). dimensão de realidade à transgressão e à resistência. Pois a palavra que vive unicamente de sua introjeção no discurso, transgride e resiste numa clandestinidade que é fim em si mesma. Poderia esta palavra abrir-se para o confronto com a lógica violenta das significações dominantes? Estaria condenada à contradição de uma resistência sem confronto? Questão evidentemente difícil e para a qual seria bom que não houvesse resposta definitiva. Entretanto, a própria consideração da profundidade da crise a que vimos aludindo e a maneira como ela vem sendo simbolicamente trabalhada pelos autores contemporâneos parecem indicar a extrema dificuldade da consideração do diálogo como possibilidade histórica. Uma dificuldade que deriva da oposição absoluta entre o discurso e a violência, tal como é afirmada, por exemplo, por Paul Ricoeur: "Tal é, inelutavelmente, nosso ponto de partida: violência e linguagem medem do início ao fim todo o campo do seu percurso, como dois contrários exatamente ajustados a toda a extensão do outro. [...]. Não se deve nunca deixar de considerar como simples verdade formal, ainda que vazia, o que foi nosso ponto de partida, a saber, que o discurso e a violência são os contrários mais fundamentais da existência humana" (Ricoeur, 1995, p. 60-67). Esta oposição absoluta não impede que a violência fale. Aí se localiza a possibilidade, já apontada por Aristóteles na Arte retórica, da palavra que persuade à injustiça. No limite, a tirania faz uso da palavra para exercer a força, para promover a violência ao estatuto de valor. Aparece então o que Ricoeur chama de "jogo turvo entre o sentido e a violência", que subverte a identificação a que já aludimos entre sentido e valor. Quando a violência invade o território da palavra, seríamos tentados a considerar, talvez com um otimismo excessivo a que não escapa Ricoeur, que a discussão está travada, que o exercício da violência deixa de ser inteiramente possível quando se aceita a palavra, pois aquele que concorda em falar tem que depor a sua arma. Mas a violência se associa à palavra exatamente para não renunciar a si própria, para utilizar a palavra num quadro de impostura que disfarça a violência mas não a suprime. "Essa palavra [impostura] imediatamente descobre todo um mundo tenebroso de palavras falsificadas que fazem da linguagem o verbo da violência. Tínhamos partido da antítese, nítida e clara, do discurso e da violência, e eis que, sobre o fundo dessa oposição formal e sempre invisível na sua própria ordem, destaca-se a frase: 'a violência fala' "(Ricoeur, 1995, p. 61). É a possibilidade deste enfrentamento dentro da linguagem que fundamenta a constituição do sentido pelo valor. Pois o discurso da violência pode ser coerente e aliciante, sedutor e persuasivo, e não será a anatomia da linguagem que descobrirá o terror sob a capa do sentido. O mascaramento indefinido da violência joga com a inércia dos termos e com o adormecimento das significações. A virulência retórica não pode se deter na palavra refletida, não pode descobrir a face interna da palavra, não pode dar tempo àquele que ouve para pensar, pois esta mediação destruiria a eficácia do estímulo e abriria o intervalo de liberdade que faz com que tornemos nossas as palavras, antes de darmos a elas a nossa anuência. O discurso da violência supõe o interlocutor 
despossuído, frágil, confuso e não senhor de suas próprias esperanças. A palavra que elege a injustiça como solo de sentido não pode encontrar lugar de expansão na subjetividade autônoma. Por isto o discurso violento se vale da repetição, da reiteração de slogans, da coerência formal, do argumento descontextualizado, da seqüência mecânica de idéias feitas. Desta maneira impede que o sentido se construa na interatividade dos agentes da fala, na tensão das subjetividades interpretantes. Mas estas características do uso violento da palavra nos levam a entender que a violência é paralela à banalização da linguagem. É a palavra decaída em código estimulador da conduta e do pensamento que destrói a dinâmica da interlocução e torna esdrúxula a relação entre liberdade e sentido, entre valor e construção das significações. A palavra banalizada se institui como secundária e subsidiária de uma outra cujo sentido imposto ela apenas reitera passivamente. O limite desta confluência entre violência e banalização é a servidão do pensamento aos códigos exteriores de aferição do sentido e de moralização da linguagem. Desta maneira se anulam todas as possibilidades de expressão como exteriorização da interioridade, e o diálogo intersubjetivo torna-se um jogo de rebatimentos de termos codificados. Daí o caráter longínquo e duvidoso do diálogo como possibilidade histórica de resgate da autonomia e da integridade ética. Talvez por isto o que Bosi chamou de autismo da linguagem literária contemporânea possa ser entendido como a solidão da palavra enquanto última instância possível da referência ética do dizer. Que a única maneira de religar a palavra ao valor do seu sentido esteja na auto-referência da fala e da escrita à sua própria consumação sinaliza para a antítese da esperança no poder iluminador do logos: o recolhimento do verbo à sombra da subjetividade que tenta escapar da barbárie rendendo-se à sua ameaça.

Diante de tudo isto, qual o sentido da transgressão e da resistência? Talvez a resposta seja que são estas as únicas formas de compromisso que pode assumir aquele que faz da palavra o meio de reinventar permanentemente o mundo. E este meio corresponde à finalidade da palavra, mesmo que a reinvenção do humano fatalmente se choque com a opacidade e a violência. $\mathrm{O}$ que sustenta o poeta na solidão do exílio - e a poesia é, na modernidade, sempre a palavra exilada - é a comunhão profunda com todas as fraquezas que os homens recalcaram, com todas as renúncias que praticaram para alimentar as ilusões da eficiência, do progresso e da dominação. Então o poeta recorda e tenta fazer recordar ${ }^{4}$, mesmo quando a memória já está habitada pela recusa do reencontro daquilo que oculta. Por isto o poeta pressente o alcance daquilo que reencontra no encontro com Mario. Pois não é da memória de Mario que surgirá o desejo de poesia e a expectativa da palavra. É uma espera humana que o poeta vem atender. É a memória humana que ele tenta despertar, para além das lembranças pesadas das desventuras históricas. Ele entrega o caderno, transmite a missão. E se a aventura da palavra se torna a desventura do homem é porque as opções humanas não mais permitem que a palavra preencha o vazio que isola os homens.
4 " $\operatorname{Re}($ cor)dar a natureza é, etimologicamente, repô-la no coração do homem [...]"(Bosi, 1977 , p. 154). 
SILVA, Franklin Leopoldo e. A dimensão ética da palavra. Tempo Social; Rev. Sociol. USP, S. Paulo, 8(2): 53-66, outubro de 1996.

Recebido para publicação em julho/1996

UNITERMS:

word,

value,

knowledge,

resistance,

Il postino.
ABSTRACT: In a world marked by violence and axiological dissolution, can Word still be good for the individual ethic constitution, as self-knowledge and knowledge of another? This is the question considered by this paper, in which we comment some views of the film I/ postino.

\section{REFERÊNCIASBIBLIOGRÁFICAS}

ARISTÓTELES. (1944) Arte retórica. I e II. Paris, Éditions Voilquin et Capelle. Paris, Garnier.

Bosi, Alfredo. (1977) O ser e o tempo da poesia. São Paulo, Cultrix/Edusp.

Lima, Waldecy Tenório de. (1955) A bailarina andaluza - A lucidez, a esperança e o sagrado na poesia de João Cabral. São Paulo. Tese (Doutorado). Departamento de Filosofia, Faculdade de Filosofia, Letras e Ciências Humanas da Universidade de São Paulo.

Nunes, Benedito. (1989) O drama da linguagem - uma leitura de Clarice Lispector. São Paulo, Ática.

Ricoeur, Paul. (1995) Violência e linguagem. In: Leituras $1-e m$ torno ao político. São Paulo, Loyola. 